\title{
An Accelerator Tied to a Brake: Fiscal Stimulus Under a Floating Exchange Rate
}

\author{
Tom Valentine ${ }^{1}$
}

\section{Abstract}

This paper examines the widely accepted proposition that the fiscal stimulus saved Australia from the worst effects of the Global Financial Crisis (GFC). It presents theoretical and empirical arguments supporting the view that fiscal stimulus is ineffective in a floating exchange-rate regime. It underlines this by comparing Australia's experiences in the East Asian Crisis of 1997 and the GFC of 2008-09. It concludes that a depreciating exchange rate protected the Australian economy in the 1997 crisis, but was prevented from doing so in the 2008-09 crisis by the fiscal stimulus.

\section{Theoretical Underpinnings}

The Mundell-Fleming model (Mundell 1963) throws light on the relative effectiveness of monetary and fiscal policy under different exchange-rate regimes. Here we will consider a very simple example of their results. We assume that capital is internationally mobile. Under this condition, the following relationship (called uncovered interest-rate parity) will be satisfied:

$$
\mathrm{R}_{\mathrm{A}}=\mathrm{R}_{\mathrm{O}}+\mathrm{e}^{*}
$$

where

$\mathrm{R}_{\mathrm{A}}=$ the Australian interest rate.

$\mathrm{R}_{\mathrm{O}}=$ the interest rate in a specific foreign currency and for the same term.

$\mathrm{e}^{*}=$ the expected depreciation of the Australian dollar against the specified currency in the period concerned.

1 Macquarie Graduate School of Management, Macquarie University; tom.v@bigpond.net.au. 
Capital flows will ensure that this relationship is satisfied. For example, if $\mathrm{R}_{\mathrm{o}}+$ $\mathrm{e}^{*}$ is greater than $\mathrm{R}_{\mathrm{A}^{\prime}}$ funds will flow out of Australia to take advantage of the perceived higher expected return overseas. This will cause either:

- an increase in $\mathrm{R}_{\mathrm{A}^{\prime}}$; or

- a fall in the value of the Australian dollar which will reduce $\mathrm{e}^{*}$.

Consider the effectiveness of monetary and fiscal policy under different exchange-rate regimes.

Fixed exchange rate: Assume that the authorities increase $\mathrm{R}_{\mathrm{A}}$. Funds will flow in (and as $\mathrm{e}^{*}=0$ ) $\mathrm{R}_{\mathrm{A}}$ will fall back. That is, monetary policy is ineffective. In general, $\mathrm{R}_{\mathrm{A}}=\mathrm{R}_{\mathrm{O}}$ so that the domestic interest rate must be equal to the interest rate in the currency against which the domestic currency is fixed.

If a budget deficit is expanded, the economy will be stimulated. That is, fiscal policy is effective.

Floating exchange rate: An increase in $\mathrm{R}_{\mathrm{A}}$ will cause an appreciation of the Australian dollar so that $\mathrm{e}^{*}$ increases, maintaining the uncovered interest-rate parity relationship. This appreciation will reinforce the tightening of monetary policy. Monetary policy is effective.

An increase in the budget deficit, however, will cause an appreciation of the Australian dollar, increasing $\mathrm{e}^{*}$. This will offset the expansionary effect of the deficit.

The conclusion of this discussion is that fiscal stimulus is likely to be ineffective in an economy with a floating exchange rate. A fiscal stimulation is an accelerator connected to a brake (the appreciating currency). This point is underlined in the next section by a basic macroeconomic model.

\section{A Macroeconomic Model Including Exchange- rate Effects}

The following macroeconomic model illustrates the points made in the previous subsection.

$$
\begin{aligned}
& \text { Expenditure, } \mathrm{C}+\mathrm{I}=\mathrm{A}+\mathrm{aCP}+\mathrm{b}(\mathrm{Y}-\mathrm{T}) \\
& \mathrm{CP}=\text { commodity price index } \\
& \text { Exports, } \mathrm{X}=-\mathrm{eE}+\mathrm{gCP} \\
& \text { Imports, } \mathrm{M}=\mathrm{d}(\mathrm{Y}-\mathrm{T})+\mathrm{hE}
\end{aligned}
$$


Exchange Rate $\mathrm{E}=\mathrm{mD}+\mathrm{nCP}$

$\mathrm{D}=$ budget deficit $=\mathrm{G}-\mathrm{T}$

The rationale for this equation is that increased government borrowing leads to capital inflow, which causes the currency to appreciate. An empirical equivalent of this equation is:

$$
\begin{array}{clll}
\mathrm{E}=0.517+0.00105 \mathrm{CP} & +4.75 \mathrm{~GB} & +0.010 \mathrm{IRD} \\
\left(9.93^{* *}\right)\left(2.75^{*}\right) & \left(3.88^{* *}\right) & -\left(2.07^{*}\right) \\
\mathrm{R}^{2}=0.442 \mathrm{~d}=1.38 & 1983-2008 &
\end{array}
$$

where

$\mathrm{E}=\mathrm{A} \$ / \mathrm{US} \$$ exchange rate

$\mathrm{CP}=\mathrm{RBA}$ commodity price index, in US dollars

$\mathrm{GB}=$ 'net lending of all public authorities' (RBA statistical tables)

IRD $=$ interest-rate differential based on three-month US and Australian interest rates

The figures under the coefficients are t-values. Asterisks indicate the level of significance, with one asterisk indicating significance at the five percent level and two asterisks indicating significance at the one percent level. (The CUSUM of squares test indicates that the relationship is stable.)

To find the equilibrium income.

$$
\begin{gathered}
\mathrm{AS}=\mathrm{AD} \\
\mathrm{Y}=\mathrm{A}+\mathrm{aCP}+\mathrm{bY}-\mathrm{bT}+\mathrm{G}+(\mathrm{X}-\mathrm{M})
\end{gathered}
$$

Therefore, $Y=\frac{A}{1-b+d}+\frac{[b-d-[c+h] m] b}{1-b+d}+G+\frac{[a+g-a[c+h]}{1-b+d} C P$

Note first that the impact of commodity prices on equilibrium income is reduced by their impact on the exchange rate, then on exports and imports $(=\mathrm{n}[\mathrm{e}+$ h]). This outcome illustrates the role that the exchange rate has in adjusting the economy to fluctuations in commodity prices. For example, an increase in commodity prices leads to an appreciation of the dollar, which reduces exports and increases imports. This reduction in net exports reduces the degree of overheating that the increase in commodity prices might otherwise engender. In this way, the floating exchange rate serves to insulate the Australian economy 
from overseas developments. Note also that the impact of the budget deficit is reduced by its effect on the exchange rate, then on exports and imports $(=\mathrm{m}[\mathrm{e}$ $+\mathrm{h}])$.

\section{Two Crises}

It is surprising that the government reacted as it did at the end of 2008 because it had a case study to inform its reactions - the Asian Crisis which began in 1997. That crisis was greeted with the same media hysteria as the GFC. However, the government did not panic or create a huge fiscal stimulus. The Australian dollar depreciated and this insulated the Australian economy from the crisis. This point seemed to be well understood by economists at the time. For example, it is discussed in the widely used textbook Layton, Robinson and Tucker (2009: 555-6).

This point is illustrated by Table 1 :

Table 1: Australian macroeconomic indicators during the East Asian Crisis

\begin{tabular}{|c|c|c|c|c|c|}
\hline & & A\$ per US\$ & $\begin{array}{l}\text { Commodity } \\
\text { Prices (US\$) }\end{array}$ & $\begin{array}{l}\text { Commodity } \\
\text { Prices (A\$) }\end{array}$ & $\begin{array}{l}\text { Unemployment } \\
\text { Rate }\end{array}$ \\
\hline \multirow[t]{4}{*}{1997} & $J$ & 0.7455 & 38.1 & 37.5 & 8.2 \\
\hline & $\mathrm{S}$ & 0.7198 & 37.4 & 38.3 & 8.1 \\
\hline & D & 0.6527 & 35.8 & 40.0 & 7.9 \\
\hline & $M$ & 0.6634 & 34.5 & 38.2 & 7.9 \\
\hline \multirow[t]{4}{*}{1998} & $\mathrm{~J}$ & 0.6135 & 32.4 & 39.8 & 7.9 \\
\hline & $\mathrm{S}$ & 0.5945 & 31.3 & 39.4 & 7.7 \\
\hline & $\mathrm{D}$ & 0.6139 & 30.7 & 36.8 & 7.3 \\
\hline & $\mathrm{M}$ & 0.6293 & 30.7 & 36.1 & 7.1 \\
\hline \multirow[t]{4}{*}{1999} & $J$ & 0.6596 & 30.3 & 34.2 & 6.7 \\
\hline & $\mathrm{S}$ & 0.6536 & 31.6 & 36.0 & 7.0 \\
\hline & $\mathrm{D}$ & 0.6538 & 31.7 & 36.7 & 6.7 \\
\hline & $\mathrm{M}$ & 0.6055 & 32.7 & 39.7 & 6.6 \\
\hline \multirow[t]{4}{*}{2000} & $\mathrm{~J}$ & 0.5986 & 33.5 & 41.8 & 6.2 \\
\hline & $\mathrm{S}$ & 0.5433 & 33.9 & 45.4 & 6.0 \\
\hline & $\mathrm{D}$ & 0.5540 & 33.3 & 45.0 & 6.3 \\
\hline & $\mathrm{M}$ & 0.4890 & 33.0 & 48.4 & 6.5 \\
\hline \multirow[t]{4}{*}{2001} & $\mathrm{~J}$ & 0.5075 & 34.0 & 48.7 & 6.9 \\
\hline & $\mathrm{S}$ & 0.4923 & 34.0 & 49.8 & 6.8 \\
\hline & $\mathrm{D}$ & 0.5106 & 32.6 & 47.0 & 6.8 \\
\hline & $\mathrm{M}$ & 0.5316 & 33.6 & 47.5 & 6.4 \\
\hline 2002 & $J$ & 0.5648 & 33.9 & 44.0 & 6.5 \\
\hline
\end{tabular}

Source: RBA Statistical Tables

The impact of the Asian Crisis is shown by the fall in the index of commodity prices in US dollar terms. However, the exchange rate fell and the index of commodity prices in Australian dollars actually went up over the period under consideration. Specifically, CP fell by 20.4 per cent over the period June 1997 
to June 1999 whereas $\mathrm{CP}(\$ \mathrm{~A})$ fell by only 8.8 per cent. Thereafter, the exchange rate depreciated further and $\mathrm{CP}(\$ \mathrm{~A})$ actually increased, although there was little change in CP. This increase was reflected in a significant reduction in the unemployment rate. This episode illustrates how a floating exchange rate insulates the economy from shocks arising overseas, making further government action unnecessary. This example also suggests that a floating exchange rate is particularly appropriate for an economy, such as Australia's, which depends on commodity exports. Commodity prices move in wide cycles and it is desirable that the exchange rate move in a counter-cyclical fashion.

The same thing was happening in the first quarter of 2009. The dollar fell and this was stimulating the economy. Growth was unexpectedly high in the first quarter of 2009 because of the contributions of net exports. Then the Australian dollar increased sharply in value in a way that was not justified by increases in commodity prices. In the fourth quarter of 2009, growth was again unexpectedly strong. However, the contribution of government spending was almost exactly offset by the negative impact from net exports. An increase in business investment made the difference, but this increase was probably due to low interest rates and improving sentiment.

The effect of the movement in the exchange rate can be tracked by examining developments in the RBA Australian dollar index of commodity prices.

Table 2: Australian macroeconomic indicators during the Global Financial Crisis

\begin{tabular}{lllll}
\hline & A\$ per US\$ & $\begin{array}{l}\text { Commodity } \\
\text { Prices (\$US) }\end{array}$ & $\begin{array}{l}\text { Commodity } \\
\text { Prices (A\$) }\end{array}$ & $\begin{array}{l}\text { Unemployment } \\
\text { Rate }\end{array}$ \\
June 2008 & 0.9626 & 116.8 & 91.0 & 4.2 \\
September 2008 & 0.7996 & 121.5 & 109.8 & 4.3 \\
December 2008 & 0.6928 & 99.2 & 109.9 & 4.6 \\
January 2009 & 0.6438 & 96.2 & 105.1 & 4.9 \\
February 2009 & 0.6454 & 92.9 & 106.1 & 5.3 \\
March 2009 & 0.6873 & 87.7 & 97.8 & 5.7 \\
April 2009 & 0.7265 & 81.0 & 84.2 & 5.5 \\
May 2009 & 0.7912 & 76.7 & 74.5 & 5.7 \\
June 2009 & 0.8114 & 79.9 & 73.8 & 5.8 \\
September 2009 & 0.8801 & 83.3 & 71.7 & 5.7 \\
December 2009 & 0.8969 & 88.3 & 72.7 & 5.5
\end{tabular}

Source: RBA Statistical Tables

Over the period June 2008 to June 2009 , CP fell by 31.6 per cent, but CP $(\$ A)$ fell by 18.9 per cent. For the remainder of $2009, \mathrm{CP}(\$ \mathrm{~A})$ continued to fall although $\mathrm{CP}$ increased. Over the period covered by the table, CP fell by 24.4 per cent and $\mathrm{CP}(\$ \mathrm{~A})$ by 20.1 per cent. This was a result of the appreciation of the Australian dollar. 
This sharp fall caused by the appreciation of the Australian dollar would have had a contractionary effect which offset the stimulatory effect of the fiscal stimulus. In addition, the 10-year bond rate increased from 4.22 per cent p.a. in December 2008 to 5.47 per cent p.a. in December 2009, which would also have had a contractionary effect. We obtained little benefit from the Australian fiscal stimulus. However, we did gain from one fiscal stimulus - the one in China. China, of course, has an exchange rate which is fixed in the short term.

\section{Conclusion}

The conclusion of this paper is that the fiscal stimulus was ineffective and, therefore, unnecessary. A similar conclusion was reached by Makin (2009) and Dixon and Rimmer (2009). It is also consistent with the accepted doctrine (at least outside Australia) that fiscal multipliers are close to zero in small open economies with a floating exchange rate (see Ilzetzki, Mendoza and Vegh 2009).

\section{References}

Dixon, P. B. and Rimmer, M. T. 2009, 'We Need Wage Moderation Not Just Demand Stimulation', Economic Papers 28(1): 63-4.

Ilzetzki, E., Mendoza, E. and Vegh, C. A. 2010, 'How big (small?) are fiscal multipliers?' NBER Working Paper No. 16479.

Layton, A., Robinson, T. and Tucker, I. B. 2009, Economics for Today, third Asian Pacific Edition, Cengage Learning, Melbourne.

Makin, A. J. 2009, 'Fiscal "stimulus": A Loanable Funds Critique', Agenda 16(4): 25-34.

Mundell, R. 1963, 'Capital Mobility and Stablization Policy Under Fixed and Flexible Exchange Rates', Canadian Journal of Economics 29: 475-85. 